\title{
Interactions Between Beet necrotic yellow vein virus and Beet soilborne mosaic virus in Sugar Beet
}

G. C. Wisler, University of Florida, Department of Plant Pathology, Gainesville 32611; R. T. Lewellen, J. L. Sears, J. W. Wasson, H.-Y. Liu, and W. M. Wintermantel, United States Department of AgricultureAgricultural Research Service, Salinas, CA 93905

\begin{abstract}
Wisler, G. C., Lewellen, R. T., Sears, J. L., Wasson, J. W., Liu, H.-Y., and Wintermantel, W. M. 2003. Interactions between Beet necrotic yellow vein virus and Beet soilborne mosaic virus in sugar beet. Plant Dis. 87:1170-1175.

Soils naturally infested with cultures of aviruliferous Polymyxa betae and viruliferous $P$. betae carrying two sugar beet benyviruses, Beet necrotic yellow vein virus (BNYVV) and Beet soilborne mosaic virus (BSBMV), alone and in combination, were compared with noninfested soil for their effects on seedling emergence, plant fresh weight, and virus content as measured by enzyme-linked immunosorbent assay (ELISA). Studies examined sugar beet with and without resistance to the disease rhizomania, caused by BNYVV. The $R z$ gene, conferring resistance to BNYVV, did not confer resistance to BSBMV. BSBMV ELISA values were significantly higher in single infections than in mixed infections with BNYVV, in both the rhizomania-resistant and -susceptible cultivars. In contrast, ELISA values of BNYVV were high ( 8 to 14 times the healthy mean) in single and mixed infections in the rhizomania-susceptible cultivar, but were low (approximately three times the healthy mean) in the rhizomania-resistant cultivar. Results indicate BNYVV may suppress BSBMV in mixed infections, even in rhizomania-resistant cultivars in which ELISA values for BNYVV are extremely low. Soils infested with $P$. betae, and with one or both viruses, showed significantly reduced fresh weight of seedlings, and aviruliferous $P$. betae significantly decreased sugar beet growth in assays.
\end{abstract}

Additional keywords: Benyvirus, Beta vulgaris, Chenopodiaceae, Polymyxa betae, rhizomania, triple-antibody sandwich ELISA

Beet necrotic yellow vein virus (BNYVV) and Beet soilborne mosaic virus (BSBMV) are members of the genus Benyvirus (9). Both viruses infect members of the family Chenopodiaceae, most notably sugar beet (Beta vulgaris L.), and are transmitted by the plasmodiophorid, Polymyxa betae $(1,2)$. BNYVV infection causes rhizomania disease in sugar beet (4,21); however, BSBMV infection does not (28). BSBMV was first described in the United States in 1988 (14), has a genome organization similar to BNYVV, and

Corresponding author: G. C. Wisler E-mail: GCWisler@mail.ifas.ufl.edu

This work has been supported in part by grants from the Beet Sugar Development Foundation, the California Sugarbeet Industry Research Committee, and the Western Sugar Research and Development Foundation.

Accepted for publication 1 May 2003.

Publication no. D-2003-0722-01R

This article is in the public domain and not copyrightable. It may be freely reprinted with customary crediting of the source. The American Phytopathological Society, 2003. a genomic sequence similarity to BNYVV ranging from 35 to $77 \%$ at the nucleotide level (10). Based on these and other studies (26), and the fact that BSBMV does not cause rhizomania, BSBMV is considered a distinct member of the genus Benyvirus $(9,24)$.

BNYVV was introduced into California (5) most likely from Europe. Based on enzyme-linked immunosorbent assay (ELISA) tests conducted at the United States Department of Agriculture-Agricultural Research Service (USDA-ARS) in Salinas, CA, BNYVV has spread throughout most states where sugar beet is grown (Idaho, Nebraska, Colorado, Oregon, Minnesota, North Dakota, Texas, Washington, Wyoming, and Michigan; 6,23,26,28). In contrast, BSBMV is not established in California, and is found primarily on the eastern slope of the Rocky Mountains and in the Midwestern beet growing states (26,27). In previous studies, isolates of BNYVV in the United States were virtually identical based on immunodiffusion, ELISA, host reactions, and results from molecular comparisons. Variability exists, however, among isolates of BSBMV from Texas, Idaho, Nebraska, and Colorado
(26). The distribution and lack of variability of BNYVV in the United States $(26,27)$ is consistent with the epidemiology of a virus that has been recently introduced. In contrast, the distribution and variability of BSBMV is indicative of a virus that is endemic, has been spread to other areas, and has evolved over a long period of time. BSBMV has not been reported in Europe.

As a result of the international significance and economic losses caused by BNYVV on sugar beet production, a breeding program was established and has been maintained in the United States since 1984 (3,11-13). A gene that induces resistance to rhizomania in sugar beet $(R z)$ was identified in 1983 from sugar beet and subsequently from wild beet (B. maritima; 3,13 ). Breeding programs have improved rhizomania resistance to the point where, even under conditions of high inoculum (i.e., the San Joaquin Valley, CA), yields and sugar production are equal to those of high-yielding, susceptible sugar beet cultivars in the absence of rhizomania (R. T. Lewellen, unpublished data). Furthermore, the level of resistance is significantly correlated with the dose of the $R z$ allele as measured by (i) root weight, (ii) the rhizomania disease index (DI) rating (from 1 to 9, where a low DI indicates resistance and lack of symptoms, and a high DI indicates susceptibility and the presence of hairy roots, a wine glass-shaped root, and internal necrosis), (iii) sugar yield, and (iv) ELISA absorbance values (25). For example, a strong negative correlation was shown between a decreasing dosage of the $R z$ allele, and both absorbance and the DI rating $(R z r z<R z r z r z<r z r z r z)$. However, a positive correlation was shown between a decreasing dosage of the $R z$ allele and root weight $(R z r z>R z r z r z>r z r z r z)$ (25). A diploid rhizomania-resistant cultivar ( $R z r z)$ has a lower virus titer and DI rating but a higher root weight than a triploid resistant cultivar (Rzrzrz), and a triploid susceptible cultivar (rzrzrz). Thus, a clear relationship was obtained between virus concentrations in BNYVV-infected plants and absorbance values with ELISA $(16,22)$.

In contrast to BNYVV, little is known about the effect of BSBMV on yield and sugar content in sugar beet. In the past 5 to 
10 years, declining yields have been a problem for sugar beet production in $\mathrm{Ne}$ braska and Colorado (8). Several causes have been suggested by industry personnel and researchers, including root rot caused by Rhizoctonia spp. or Fusarium spp., leafspot caused by Cercospora spp., root maggot, poor germination, and rhizomania. In 24 of 27 declining fields tested, however, BSBMV was present, and no BNYVV was detected (G. C. Wisler, unpublished data). If BSBMV has a negative effect on yield and sugar production, a breeding program against this virus would be justified. No empirical information on the combined effects of BNYVV and BSBMV on beet production is available. However, reciprocal cross protection for BSBMV and BNYVV has been demonstrated in mechanical inoculation trials of sugar beet seedlings (15). The two benyviruses occur either singly or as mixed infections in different areas of the United States.

The objectives of this study were to (i) determine if the $R z$ gene confers resistance to BSBMV and (ii) determine the effects of $P$. betae, BNYVV, and BSBMV, alone and in combination, on growth and relative ELISA values in sugar beet.

\section{MATERIALS AND METHODS}

Maintenance of soil cultures. BNYVVinfested soil was collected from sugar beet fields that had been infested since the late 1980 s and consistently used in rhizomania cultivar trials at the USDA-ARS in Salinas, CA. Tests are routinely made in these rhizomania fields for BSBMV, and it has never been detected there. BSBMVinfested soil was obtained from sugar beet fields near Scottsbluff, NB and was provided by Eric Kerr (University of Nebraska). Aviruliferous, $P$. betae-infested soil was obtained from river sand that was collected during a rhizomania survey conducted in eastern Wyoming in 1991, and was provided by Gary D. Franc (University of Wyoming). Roots from seedlings grown in soil containing this $P$. betae isolate were repeatedly tested by mechanical passage to the local lesion host, Chenopodium quinoa, for the presence of both soilborne viruses, and no viruses were detected. This involved grinding $P$. betae-infested root tissue in $100 \mathrm{mM}$ sodium phosphate buffer with $0.1 \%$ sodium sulfite, and rub inoculating young $C$. quinoa leaves, using celite as an abrasive. Similarly, all virusinfested soils and virus-free soils were tested prior to these studies to confirm the presence or absence of the desired viruses. Likewise, sugar beet plants grown in these soils were consistently negative in ELISA for BNYVV and BSBMV. Noninfested soil consisted of loamy sand collected from the nearby dry bed of the Salinas River, and was autoclaved prior to use. Soil samples previously identified as singly infested with viruliferous $P$. betae containing BNYVV or BSBMV and soils containing aviruliferous $P$. betae were increased in pot culture in the greenhouse, then stored at $4^{\circ} \mathrm{C}$ for this study. Soil samples were increased by mixing equal volumes of the infested soil with autoclaved sand, overlaying with sugar beet seed, and growing seedlings in pots in the greenhouse for 6 weeks. Subsequently, roots were washed free of soil and tested by ELISA for both viruses to confirm the presence or absence of each virus as needed for the experiment. Roots and accompanying soil were air dried, mixed thoroughly back into their respective soils, and stored at $4^{\circ} \mathrm{C}$.

Soil samples were mixed in equal parts with autoclaved builders' sand to facilitate ease of root removal at harvest. Greenhouse benches were washed in $10 \%$ sodium hypochlorite prior to use. Pots were new 280-ml Styrofoam cups with holes punched in the bottom for drainage and were placed in sterilized plastic saucers spaced on greenhouse benches to avoid contamination by splashing water between cups. A list of computer-generated random numbers was used to determine the placement of each cup on the greenhouse benches for a completely random design. After cups were filled with the appropriate soil sample, they were drenched with fungicides (Apron 25W $\left[0.2 \mathrm{~g}^{-1}\right]$ and Terraclor $75 \mathrm{~W}\left[0.25 \mathrm{~g}^{-1}\right]$ ) to help control damping off and root rotting caused by Pythium spp. and Rhizoctonia spp. Approximately 100 sugar beet seed (Beta4330R [Rzrz; resistant] or KWS6770 [rzrzrz; susceptible]) (R. T. Lewellen, unpublished data) were layered on top of each pot. Seed within each pot were covered with sand to a depth of about $1 \mathrm{~cm}$, and the pots were watered with gentle misting as needed to germinate sugar beet seedlings. Following germination, water was added to the saucers directly as needed to prevent wilting. Greenhouses were maintained between 15 and $24^{\circ} \mathrm{C}$ without supplemental light. Tests were conducted sequentially through the year.

The treatments in test 1 consisted of: (i) noninfested soil, (ii) BSBMV-infested soil, (iii) BNYVV-infested soil, and (iv) BNYVV- and BSBMV-infested soil, mixed in equal parts. In this test, only the rhizomania-susceptible cultivar (KWS6770) was used. Samples were harvested weekly for 6 weeks starting 2 weeks post emergence of seedlings. Each treatment combination (soil-harvest date) consisted of 6 pots each for a total of 24 pots weekly.

In tests 2 and 3, aviruliferous Polymyxa betae-infested soil was added as a treatment, and a rhizomania-resistant cultivar (Beta 4430R) also was included. In these two tests, each treatment combination (soil-cultivar-harvest date) consisted of three pots each. Roots from these pots were harvested and tested at weekly intervals for 6 weeks, for a total of 30 pots weekly.
Serological assays. A triple-antibody sandwich (TAS)-ELISA was developed in collaboration with Agdia, Inc. (Elkhart, IN) that was specific for BNYVV. Polyclonal antiserum, used as the trapping antibody, was prepared from BNYVV coat protein (CP) expressed in vitro from a clone provided by $\mathrm{K}$. Richards (INRA, Strasbourg, France) (26). The BNYVV CP expressed from the pETH plasmid was produced in Escherichia coli strain BL21DE3pLysS was identified by Western blot (20). Antiserum was prepared in rabbits to the expressed CP by Berkeley Antibodies (Richmond, CA) (26). This antiserum was used to coat microtiter plates according to Agdia protocols. The monoclonal antibody used as the detecting antibody and the conjugate also were used according to Agdia protocols.

The double-antibody sandwich ELISA was used to test for BSBMV. Polyclonal antiserum against BSBMV was developed by H.-Y. Liu. Purified immunoglobulin G (IgG) made to BSBMV (1 mg/ml) was used to coat microtiter plates at a 1/1,000 dilution, and plates were incubated at room temperature for $1 \mathrm{~h}$. After washing with $200 \mu$ of phosphate-buffered saline (PBS)Tween (0.05 M PBS, pH 7.2, with $0.5 \%$ Tween 20 and $0.4 \%$ dry milk powder) per well ( $3 \times$ for 3 min each), $200 \mu$ l of root extract (diluted $0.5 \mathrm{~g} / 2 \mathrm{ml}$ ) was added to each well and allowed to incubate overnight at $4^{\circ} \mathrm{C}$. Plates were again washed with PBS-Tween. Alkaline phosphataseconjugated anti-BSBMV IgG was added to wells (200 $\mu \mathrm{l}$ of $1 / 1,000$ dilution). Plates were incubated for $1 \mathrm{~h}$ at $37^{\circ} \mathrm{C}$, then washed with PBS-Tween again. Alkaline phosphatase substrate pellets (SigmaAldrich, St. Louis) were used at a ratio of 1 pellet per $8.3 \mathrm{ml}$ of substrate buffer. All other standard ELISA techniques are described by Agdia, Inc.

Plant samples consisted of sugar beet roots collected from each Styrofoam cup that were washed free of remaining soil. Root tissue from each cup $(0.5 \mathrm{~g}$ from each root mass) was added to $2 \mathrm{ml}$ of extraction buffer (PBS-Tween). Root tissues were homogenized in sample extraction bags with a hand-held roller press (Agdia, Inc.). Expressed sap $(150 \mu \mathrm{l}$ per well) was added to each of two wells of a microtiter plate. A list of computer-generated random numbers was used to determine the placement of the test samples per harvest date on microtiter plates. Each plate also contained paired wells with (i) sample buffer only, (ii) BNYVV-infected beet roots, (iii) BSBMV-infected beet roots, (iv) healthy beet roots, (v) leaf tissue from BNYVVsystemically infected $B$. macrocarpa Guss. plants, (vi) leaf tissue from BSBMV-systemically infected $B$. macrocarpa, and (vii) leaf tissue from healthy $B$. macrocarpa. The BNYVV monoclonal antibody used as the detecting antibody in the TAS-ELISA and the goat-anti-mouse IgG-alkaline 
phosphatase conjugate were provided by Agdia and used according to instructions. Absorbance readings at $405 \mathrm{~nm}\left(A_{405 \mathrm{~nm}}\right)$ were made at 15 -min intervals for up to $2 \mathrm{~h}$ with a Bio-Tek EL312e microplate reader (Winooski, VT). All reported ELISA values were for a 2 -h period and represent the ratio of the test sample absorbance at $A_{405 \mathrm{~nm}}$ divided by the absorbance of the healthy sample. Ratios of $\geq 3$ times the healthy mean were considered to be positive, because this is the sugar beet industry standard for BNYVV confirmation and is used widely by numerous labs in the United States and Europe. This threshold has been established through years of testing to be a safe cutoff value to distinguish healthy from infected root samples.

Data analysis. Data were obtained for each individual pot and used in statistical analyses. At each harvest, the number of plants per pot was determined and all plants within a pot were combined, blotted, dried, and weighed. After the fresh weight was obtained, the combined roots of each pot were tested for BNYVV and BSBMV by ELISA as described above. For all three tests, each treatment combination was grown in a completely randomized design. Analyses of variance were run using MSTAT-C (Michigan State University, June 1991).

\section{RESULTS}

Statistical analyses. The mean squares and levels of significance from the analyses of variance for the variables in the three tests are shown in Table 1. The main effect means for cultivars, soil treatments, and harvest dates for all three tests are shown in Table 2. As needed, to illustrate specific results, interaction means are shown in Tables 3, 4, and 5.

Rhizomania resistance gene. Resistance to rhizomania caused by BNYVV and conferred by the $R z$ allele did not con- fer resistance to BSBMV in sugar beet in greenhouse pot cultures (Tables 1 and 2). ELISA values for BNYVV in the rhizomania-susceptible cv. KWS6770 were significantly higher than in the resistant (Beta4430R) cultivar (Table 3). Minimal differences occurred for the ELISA values of BSBMV between these cultivars when tested as single infections across all six harvest dates in test 2 , but not in test 3 (Table 3). A significant cultivar-soil treatment interaction occurred for BNYVV but not for BSBMV (Table 1 and 3).

Effect of BSBMV on sugar beet. In all three tests, total plant fresh weight was significantly decreased by infection with BSBMV and BNYVV (Table 2). Although the plant weights in the BSBMV treatments were significantly lower than those of the seedlings in the healthy treatments, plant weights measured for BNYVV and for mixed infections were even lower than for BSBMV (Table 2).

Table 1. Mean squares from analyses of variance for enzyme-linked immunosorbent assay values for Beet necrotic yellow vein virus (BNYVV) and Beet soilborne mosaic virus (BSBMV), and total fresh plant weight for rhizomania-resistant (Beta 4430R) and -susceptible (KWS6770) cultivars grown under five soil treatments and harvested at 6 weekly dates

\begin{tabular}{|c|c|c|c|c|c|c|c|c|c|c|c|c|}
\hline \multirow[b]{3}{*}{ Source $^{x}$} & \multicolumn{12}{|c|}{ Mean squaresw } \\
\hline & \multicolumn{4}{|c|}{ Test 1} & \multicolumn{4}{|c|}{ Test 2} & \multicolumn{4}{|c|}{ Test 3} \\
\hline & df & BNYVVy & BSBMV $^{\mathbf{y}}$ & Weight $(\mathbf{g})^{\mathrm{z}}$ & df & BNYVV & BSBMV & Weight (g) & df & BNYVV & BSBMV & Weight (g) \\
\hline $\mathrm{C}$ & $\ldots$ & $\ldots$ & $\ldots$ & $\ldots$ & 1 & $463 * *$ & $10 \mathrm{~ns}$ & $460 * *$ & 1 & $69.3 * *$ & $0.1 \mathrm{~ns}$ & $1,441 * *$ \\
\hline $\mathrm{S}$ & 3 & $798 * *$ & $1,572 * *$ & $6,287 * *$ & 4 & $287 * *$ & $357 * *$ & $5,714 * *$ & 4 & $108.3^{* *} *$ & $53.1 * *$ & $726 * *$ \\
\hline $\mathrm{C} \times \mathrm{S}$ & na & na & na & na & 4 & $177 * *$ & $7 \mathrm{~ns}$ & $18 \mathrm{~ns}$ & 4 & $42.7 * *$ & $0.2 \mathrm{~ns}$ & $18 * *$ \\
\hline $\mathrm{H}$ & 5 & $142 * *$ & $139 \mathrm{~ns}$ & $2,966 * *$ & 5 & $37 * *$ & $52 * *$ & $464 * *$ & 5 & $15.6^{* *}$ & $6.6 \mathrm{~ns}$ & $62 * *$ \\
\hline $\mathrm{C} \times \mathrm{H}$ & na & na & na & na & 5 & $25 * *$ & $4 \mathrm{~ns}$ & $14 \mathrm{~ns}$ & 5 & $19 * *$ & $6.4 \mathrm{~ns}$ & $8 *$ \\
\hline $\mathrm{S} \times \mathrm{H}$ & 15 & $52 * *$ & $157 \mathrm{~ns}$ & $65^{* *}$ & 20 & $27 * *$ & $46 * *$ & $55^{* *}$ & 20 & $7.7 * *$ & $4.4 \mathrm{~ns}$ & $13^{* *}$ \\
\hline $\mathrm{C} \times \mathrm{S} \times \mathrm{H}$ & na & na & na & na & 20 & $19 * *$ & $4 \mathrm{~ns}$ & $10 \mathrm{~ns}$ & 20 & $8.6^{* *}$ & $6.0 \mathrm{~ns}$ & $5 \mathrm{~ns}$ \\
\hline Error & 120 & 7 & 260 & 16 & 120 & 5.6 & 6.2 & 7.8 & 120 & 3.6 & 3.9 & 3.5 \\
\hline
\end{tabular}

${ }^{\text {w }}$ Tests 1,2 , and 3: completely random design with three repetitions; na $=$ not applicable; ns $=$ not significant; $*$ and $* *$ indicate significance at the $P \leq$ 0.05 and 0.01 levels, respectively, according to the $F$ test.

x Source of variation: cultivar $(\mathrm{C})$, soil $(\mathrm{S})$, and harvest date $(\mathrm{H})$.

$\mathrm{y}$ Values represent the ratio of the absorbance (at $405 \mathrm{~nm}$ ) reading for BNYVV or BSBMV over the corresponding healthy absorbance value.

$\mathrm{z}$ Total fresh weight of plants per pot.

Table 2. Main effect treatment means for enzyme-linked immunosorbent assay values for Beet necrotic yellow vein virus (BNYVV), Beet soilborne mosaic virus (BSBMV), and total plant fresh weight evaluated for one (test 1) or two (tests 2 and 3 ) cultivars over five soil treatments and six weekly harvest dates ${ }^{\mathrm{y}}$

\begin{tabular}{|c|c|c|c|c|c|c|c|c|c|}
\hline \multirow[b]{2}{*}{ Treatments $^{\mathrm{z}}$} & \multicolumn{3}{|c|}{ Test 1} & \multicolumn{3}{|c|}{ Test 2} & \multicolumn{3}{|c|}{ Test 3} \\
\hline & BNYVV & BSBMV & Weight (g) & BNYVV & BSBMV & Weight (g) & BNYVV & BSBMV & Weight (g) \\
\hline Grand mean & 5.0 & 5.1 & 39.4 & 3.0 & 2.5 & 21.6 & 2.1 & 1.7 & 9.3 \\
\hline \multicolumn{10}{|l|}{ Cultivar } \\
\hline Susceptible (rzrzrz) & na & na & na & $4.7 \mathrm{a}$ & $2.8 \mathrm{a}$ & $20.0 \mathrm{a}$ & $2.7 \mathrm{a}$ & $1.6 \mathrm{a}$ & $6.4 \mathrm{a}$ \\
\hline Resistant (Rzrz) & na & na & na & $1.4 \mathrm{~b}$ & $2.3 \mathrm{a}$ & $23.2 \mathrm{~b}$ & $1.5 \mathrm{~b}$ & $1.7 \mathrm{a}$ & $12.1 \mathrm{~b}$ \\
\hline \multicolumn{10}{|l|}{ Soil treatment } \\
\hline Noninfested & $1.0 \mathrm{c}$ & $1.0 \mathrm{~b}$ & $58.9 \mathrm{a}$ & $1.0 \mathrm{~b}$ & $1.0 \mathrm{~b}$ & $39.8 \mathrm{a}$ & $1.0 \mathrm{c}$ & $1.0 \mathrm{~b}$ & $17.0 \mathrm{a}$ \\
\hline Polymyxa betae & nt & nt & nt & $1.0 \mathrm{~b}$ & $1.0 \mathrm{~b}$ & $27.6 \mathrm{~b}$ & $1.0 \mathrm{c}$ & $1.0 \mathrm{~b}$ & $9.1 \mathrm{~b}$ \\
\hline BSBMV & $1.1 \mathrm{c}$ & 14. $9 \mathrm{a}$ & $35.8 \mathrm{~b}$ & $1.0 \mathrm{~b}$ & $8.2 \mathrm{a}$ & $20.5 \mathrm{c}$ & $1.0 \mathrm{c}$ & $3.8 \mathrm{a}$ & $7.7 \mathrm{c}$ \\
\hline BNYVV & $7.9 \mathrm{~b}$ & $1.1 \mathrm{~b}$ & $32.6 \mathrm{c}$ & $6.6 \mathrm{a}$ & $1.1 \mathrm{~b}$ & $9.7 \mathrm{~d}$ & $5.0 \mathrm{a}$ & $1.1 \mathrm{~b}$ & $6.6 \mathrm{~d}$ \\
\hline Mixed infection & $10.2 \mathrm{a}$ & $3.5 \mathrm{~b}$ & $30.2 \mathrm{~d}$ & $5.7 \mathrm{a}$ & $1.3 \mathrm{~b}$ & $10.4 \mathrm{~d}$ & $2.4 \mathrm{~b}$ & $1.4 \mathrm{~b}$ & $5.9 \mathrm{~d}$ \\
\hline \multicolumn{10}{|l|}{ Harvest date } \\
\hline Week 1 & $3.6 \mathrm{c}$ & $9.2 \mathrm{a}$ & $21.4 \mathrm{f}$ & $2.4 \mathrm{bc}$ & $1.3 \mathrm{c}$ & $15.3 \mathrm{~d}$ & $1.6 \mathrm{~b}$ & $1.0 \mathrm{a}$ & $7.0 \mathrm{e}$ \\
\hline Week 2 & $8.3 \mathrm{a}$ & $2.9 \mathrm{a}$ & $33.4 \mathrm{e}$ & $3.3 \mathrm{~b}$ & $2.7 \mathrm{bc}$ & $19.4 \mathrm{c}$ & $2.1 \mathrm{ab}$ & $1.8 \mathrm{a}$ & $8.5 \mathrm{~d}$ \\
\hline Week 3 & $6.4 \mathrm{~b}$ & $3.8 \mathrm{a}$ & $39.1 \mathrm{~d}$ & $2.4 \mathrm{bc}$ & $1.9 \mathrm{bc}$ & $20.8 c$ & $1.5 \mathrm{~b}$ & $2.1 \mathrm{a}$ & $9.1 \mathrm{~cd}$ \\
\hline Week 4 & $6.7 \mathrm{ab}$ & $6.8 \mathrm{a}$ & $41.8 \mathrm{c}$ & $1.9 \mathrm{c}$ & $3.1 \mathrm{~b}$ & $23.6 \mathrm{~b}$ & $1.4 \mathrm{~b}$ & $1.2 \mathrm{a}$ & $9.6 \mathrm{bc}$ \\
\hline Week 5 & $2.8 \mathrm{c}$ & $3.5 \mathrm{a}$ & $48.1 \mathrm{~b}$ & $5.0 \mathrm{a}$ & $4.8 \mathrm{a}$ & $25.3 \mathrm{a}$ & $3.0 \mathrm{a}$ & $2.1 \mathrm{a}$ & $11.2 \mathrm{a}$ \\
\hline Week 6 & $2.4 \mathrm{c}$ & $4.5 \mathrm{a}$ & $52.6 \mathrm{a}$ & $3.3 \mathrm{~b}$ & $1.4 \mathrm{c}$ & $25.4 \mathrm{a}$ & $3.0 \mathrm{a}$ & $1.9 \mathrm{a}$ & $10.3 \mathrm{ab}$ \\
\hline
\end{tabular}

y The value for the mean healthy check for both viruses is 1.0 . Means within columns followed by a different letter are significant at $P \leq 0.05$ according to the Duncan's multiple range test; na = not applicable; $\mathrm{nt}=$ not tested.

${ }^{\mathrm{z}}$ Susceptible cultivar $=$ KWS6770 and resistant cultivar $=$ Beta4430R . 
Effects of $P$. betae on sugar beet. In greenhouse pot culture, aviruliferous $P$. betae caused a significant reduction in sugar beet growth (tests 2 and 3), as measured by reduced plant weight (Table 2). ELISA values with BNYVV and BSBMV antiserum were equal to readings of noninfected plants harvested from the aviruliferous $P$. betae-infested soil and the noninsorbance ratio of 1.0 for a test sample to a healthy control showed that there was no contamination with either virus in the $P$. betae-infested or in sterile soils. Infection by aviruliferous $P$. betae caused a significant reduction in plant weight for both resistant and susceptible cultivars (Table 4).

Mixed infections with benyviruses. In test 1 , where only the rhizomania-susceptible cv. KWS6770 was used, ELISA values from roots for BSBMV were significantly reduced from 14.9 times the healthy mean in single infections to values only 3.5 times fested soil treatments (Table 5). An ab-

higher than the healthy mean in mixed infections with BNYVV (Table 5). In contrast, ELISA values from tissue infected by BNYVV were 7.9 times the healthy mean in single infections and 10.2 times the healthy mean in mixed infections (Table 5). Tests 2 and 3 involved both resistant and susceptible cultivars. In these tests, ELISA values from BSBMV-infected roots were significantly reduced when plants were grown in soil containing both viruses compared with plants grown in singly infested soil with either rhizomaniasusceptible or -resistant cultivars (Table 5). The exception was test 3, in which ELISA values for plants grown in soil containing both viruses, while lower than values for soil singly infested with BSBMV, were not significantly different (Table 5). In tests 2 and 3, ELISA values for BNYVV from susceptible sugar beet roots (KWS6770) were lower when plants were grown in soil containing both viruses compared with

Table 3. Enzyme-linked immunosorbent assay value interaction means between resistant and susceptible sugar beet cultivars and soil treatments for Beet necrotic yellow vein virus (BNYVV) and Beet soilborne mosaic virus $(\mathrm{BSBMV})^{\mathrm{z}}$

\begin{tabular}{|c|c|c|c|c|}
\hline \multirow[b]{2}{*}{ Treatment interactions } & \multicolumn{2}{|c|}{ Test 2} & \multicolumn{2}{|c|}{ Test 3} \\
\hline & BNYVV & BSBMV & BNYVV & BSBMV \\
\hline Susceptible-BSBMV soil & $1.0 \mathrm{~b}(-)$ & $9.2 \mathrm{a}(+)$ & $1.0 \mathrm{c}(-)$ & $3.7 \mathrm{a}(+)$ \\
\hline Susceptible-BNYVV soil & $11.2 \mathrm{a}(+)$ & $1.1 \mathrm{c} \mathrm{(-)}$ & $7.5 \mathrm{a}(+)$ & $1.0 \mathrm{~b}(-)$ \\
\hline Resistant-BSBMV soil & $1.0 \mathrm{~b}(-)$ & $7.1 \mathrm{~b}(+)$ & $1.0 \mathrm{c}(-)$ & $4.0 \mathrm{a}(+)$ \\
\hline Resistant-BNYVV soil & $1.9 \mathrm{~b}(-)$ & $1.1 \mathrm{c}(-)$ & $2.5 \mathrm{~b}(-)$ & $1.2 \mathrm{~b}(-)$ \\
\hline
\end{tabular}

${ }^{\mathrm{z}}$ Values represent the ratio of the absorbance (at $405 \mathrm{~nm}$ ) reading for BNYVV or BSBMV over the corresponding healthy absorbance value. Means within columns followed by a different letter are significant at $P \leq 0.05$ according to the Duncan's multiple range test. Ratios of $\geq 3$ times the healthy mean are considered positive $(+)$. Means are for 18 pots across six dates of harvest and three repetitions.

Table 4. Effects of aviruliferous Polymyxa betae-infested soil on plant weight in rhizomaniasusceptible and -resistant sugar beet cultivars ${ }^{\mathrm{z}}$

\begin{tabular}{lcc}
\hline & \multicolumn{2}{c}{ Plant weight $(\mathbf{g})$} \\
\cline { 2 - 3 } Treatments & Test $\mathbf{2}$ & Test 3 \\
\hline Susceptible $\times$ noninfested soil & $38 \mathrm{~b}$ & $14 \mathrm{~b}$ \\
Susceptible $\times P$. betae soil & $27 \mathrm{~d}$ & $6 \mathrm{c}$ \\
Resistant $\times$ noninfested soil & $42 \mathrm{a}$ & $20 \mathrm{a}$ \\
Resistant $\times P$. betae soil & $29 \mathrm{c}$ & $12 \mathrm{~b}$ \\
\hline
\end{tabular}

${ }^{\mathrm{z}}$ Means are for 18 pots across six harvest dates and three repetitions. Means within columns followed by a different letter are significant at $P \leq 0.05$ according to the Duncan's multiple range test. values from plants grown in singly infested soil (Table 5). In test 2, the ELISA reading for BNYVV-infected tissues of the susceptible cultivar were decreased from 11.2 to 9.0 times the healthy mean between single and mixed infections, and from 7.5 to 3.1 in test 3 . Readings were still considered positive for BNYVV in both cases. For the resistant cv. Beta4430R, BNYVV ELISA values were consistently negative when plants were grown in either singly infested soil or soil containing both viruses (Table 5).

\section{DISCUSSION}

Several important conclusions were made for the effects of (i) P. betae, (ii) BSBMV, and (iii) mixed infections of BNYVV and BSBMV on the growth of sugar beet in greenhouse pot culture. The three tests reported here were conducted sequentially over 1 year, with different day lengths and growth potential throughout the year. Test 3 was run under the shortest day lengths. Nevertheless, the same significant effects were observed (even though differences occurred for growth rate as measured by fresh plant weight).

The use of ELISA for detection of BNYVV (7) is highly reliable, and has been accepted as the sugar beet industry standard for confirmation of rhizomaniainfested fields since the late 1980s $(7,25,26)$. Using antisera developed at the USDA-ARS in Salinas, this technique results in low absorbance values in negative samples and requires absorbance values at least three times healthy controls to achieve a positive score, and, therefore, is highly selective in identifying BNYVVinfested soils. The same scoring technique is used for confirmation of fields infested with BSBMV, using BSBMV-specific antisera (26). These methods identify field soil infested with viruliferous $P$. betae containing BNYVV, BSBMV, or both viruses with a high degree of accuracy.

Significant differences occurred for cultivars, soil treatments, and harvest dates for the measurements of ELISA values for BNYVV, BSBMV, and fresh plant weight in all three tests (Table 1). Simple and three-way interactions for some combina-

Table 5. Enzyme-linked immunosorbent assay values for Beet necrotic yellow vein virus (BNYVV) and Beet soilborne mosaic virus (BSBMV) in single and mixed infections in rhizomania-resistant and -susceptible sugar beet cultivars ${ }^{\mathrm{z}}$

\begin{tabular}{|c|c|c|c|c|c|c|c|c|c|c|}
\hline \multirow[b]{3}{*}{ Soil treatment } & \multirow{2}{*}{\multicolumn{2}{|c|}{$\begin{array}{c}\text { Test } 1 \\
\text { Susceptible }\end{array}$}} & \multicolumn{4}{|c|}{ Test 2} & \multicolumn{4}{|c|}{ Test 3} \\
\hline & & & \multicolumn{2}{|c|}{ Resistant } & \multicolumn{2}{|c|}{ Susceptible } & \multicolumn{2}{|c|}{ Resistant } & \multicolumn{2}{|c|}{ Susceptible } \\
\hline & BNYVV & BSBMV & BNYVV & BSBMV & BNYVV & BSBMV & BNYVV & BSBMV & BNYVV & BSBMV \\
\hline Noninfested & $1.0 \mathrm{c}(-)$ & $1.0 \mathrm{~b}(-)$ & $1.0 \mathrm{a}(-)$ & $1.0 \mathrm{~b}(-)$ & $1.0 \mathrm{c}(-)$ & $1.0 \mathrm{~b}(-)$ & $1.0 \mathrm{c}(-)$ & $1.0 \mathrm{a}(-)$ & $1.0 \mathrm{c}(-)$ & $1.0 \mathrm{~b} \mathrm{(-)}$ \\
\hline Polymyxa betae & nt & $\mathrm{nt}$ & $1.0 \mathrm{a}(-)$ & $1.0 \mathrm{~b}(-)$ & $1.0 \mathrm{c}(-)$ & $1.0 \mathrm{~b}(-)$ & $1.1 \mathrm{c}(-)$ & $1.1 \mathrm{a}(-)$ & $1.0 \mathrm{c}(-)$ & $1.0 \mathrm{~b}(-)$ \\
\hline BSBMV & $1.1 \mathrm{c}(-)$ & $14.9 \mathrm{a}(+)$ & $1.0 \mathrm{a}(-)$ & $7.1 \mathrm{a}(+)$ & $1.0 \mathrm{c}(-)$ & $9.2 \mathrm{a}(+)$ & $1.0 \mathrm{c}(-)$ & $4.0 \mathrm{a}(+)$ & $1.0 \mathrm{c}(-)$ & $3.7 \mathrm{a}(+)$ \\
\hline BNYVV & $7.9 \mathrm{~b}(+)$ & $1.1 \mathrm{~b}(-)$ & 1.9 a (-) & $1.1 \mathrm{~b}(-)$ & $11.2 \mathrm{a}(+)$ & $1.1 \mathrm{~b}(-)$ & $2.5 \mathrm{ab}(-)$ & $1.2 \mathrm{a}(-)$ & $7.5 \mathrm{a}(+)$ & $1.0 \mathrm{~b}(-)$ \\
\hline Mixed infection & $10.2 \mathrm{a}(+)$ & $3.5 \mathrm{~b}(+)$ & $2.4 \mathrm{a}(-)$ & $1.2 \mathrm{~b}(-)$ & $9.0 \mathrm{~b}(+)$ & $1.5 \mathrm{~b}(-)$ & $1.7 \mathrm{bc}(-)$ & $1.3 \mathrm{a}(-)$ & $3.1 \mathrm{~b}(+)$ & $1.4 \mathrm{~b}(-)$ \\
\hline
\end{tabular}

$\bar{z}$ Values represent the ratio of the absorbance at $405 \mathrm{~nm}$ reading for BNYVV or BSBMV over the corresponding healthy absorbance value. Means within columns followed by a different letter are significant at $P \leq 0.05$ according to Duncan's multiple range test; nt $=$ not tested. Ratios of $\geq 3$ times the healthy mean are considered positive (+). The value for the mean healthy check for both viruses is 1.0. Means for test 1 are for 36 pots across six harvest dates and six repetitions. Means for tests 2 and 3 are for 18 pots across six harvest dates and three repetitions. 
tions also were significant and gave important insights that these tests were able to identify differences and separate important contrasts. However, cursory observation of the virus ELISA values over time (harvest dates) might suggest that experimental error was of concern. The mean ELISA values for BNYVV- and BSBMV-infected tissue collected in weekly harvests over the course of the three tests were highly variable and did not fit a definitive or symmetrical pattern (Table 5). Similar results have been observed repeatedly at the USDA-ARS in Salinas, CA (G. C. Wisler, unpublished results) for BNYVV-infected plants, in particular. Infection of sugar beet by BNYVV is highly dependent on soil moisture and temperature, which directly influence the release and infection of roots by $P$. betae zoospores (22). The erratic ELISA values seen in field and greenhouse experiments reflect inoculation and infection by $P$. betae and BNYVV. To a large degree, the titer of the virus is probably tightly synchronized with the initiation and development of new roots and zoospore release (27). Thus, whatever environmental and physiological processes govern root initiation and proliferation of zoospores probably also affect virus titer. Even in the presence of definitive Rhizomania root symptoms, field-grown beets can be negative in ELISA due to conditions that are not conducive to $P$. betae infection $(\mathrm{G}$. C. Wisler, unpublished data). When these symptomatic beets are planted into pasteurized soil and regrown in the greenhouse through several vector-virus infection cycles, they later test positive for BNYVV by ELISA. It is less clear, in the greenhouse pot tests presented here, what factors contributed to the cycling of root development and continuous re-infection. One logical explanation for the observed variability in virus levels throughout these tests is such a cycling process, although this remains to be proven.

The detrimental effects of rhizomania on sugar beet, induced by BNYVV, have been clearly demonstrated over many years of research $(4,21,25)$. Symptoms include general yellowing and wilting and, occasionally, the necrotic yellow vein symptom is expressed (21). In addition, rhizomania infection results in an economically significant reduction in sugar content and yield $(12,21,25)$. In contrast, although BSBMV has been observed in beets for over 15 years in the United States $(14,19,28)$, the effects of this virus on beet production are largely unknown. If BSBMV has a deleterious effect on beet production, and if it were related closely enough to BNYVV for the $R z$ allele to confer resistance to it, any effects of BSBMV on sugar beet would be reduced through planting of germ plasm containing the $R z$ resistance gene. Similarities between BSBMV and BNYVV include particle morphology, particle size distribution, genome organization, and distant serological relationships $(9,10,28)$. At one time, it was suggested that BSBMV could be a strain or possibly a deletion mutant of BNYVV (17-19). If this were true, then conference of resistance by the $R z$ allele would be expected. However, it has since been demonstrated that BSBMV is clearly distinct from BNYVV, both serologically and molecularly $(10,18,27)$ and, based upon the results presented in this paper, the $R z$ allele does not provide resistance to BSBMV.

In preliminary greenhouse studies, using serial dilutions of aviruliferous $P$. betaeinfested soil, this fungus alone could reduce emergence and growth of sugar beet (G. C. Wisler, unpublished data). In the work presented here, a significant reduction in seedling weight occurred when sugar beet seedlings were infected with $P$. betae, compared with beet grown in noninfested soil (Table 4). This outcome was found for both rhizomania-susceptible and -resistant cultivars. Little is known about the incidence and distribution of $P$. betae in the absence of BNYVV or BSBMV. If aviruliferous $P$. betae is common in sugar beet fields, a negative impact on sugar beet yield could be expected. In the virus-trapping procedure used at Salinas (7), soil samples submitted by the sugar beet industry from the Eastern Slope area of the Rocky Mountains often have inhibited or reduced seedling emergence and stand establishment (G. C. Wisler, unpublished data), despite many samples having neither BNYVV nor BSBMV. This has been true even in many instances when these soils tested negative for both viruses by ELISA. These soils may have an endemic infestation of $P$. betae, although this assumption remains to be verified.

BSBMV alone accumulates well in both rhizomania-resistant and -susceptible cultivars. When BSBMV existed as mixed infections with BNYVV, the levels of BSBMV were significantly reduced in all but one experiment, even when BNYVV levels were extremely low, as seen in the rhizomania-resistant cultivar (Table 5). Even in the one exception, BSBMV levels were substantially reduced, even though differences were not significant. After results from test 1 were evaluated using only the BNYVV-susceptible cultivar, we expected that, when these two viruses occur together, BSBMV levels might be elevated if BNYVV levels were reduced in a resistant cultivar. Contrary to our expectations, however, ELISA values for BSBMV were reduced even in the rhizomania-resistant cultivar in which levels of BNYVV, while present, were below the positive scoring threshold. The ELISA values for BNYVV also were reduced in tests 2 and 3 in the susceptible cultivar, when in combination with BSBMV, although the ELISA values for BNYVV are still considered positive. It is possible that interference or competition may occur between BNYVV and BSBMV when they coexist. The significant reduction in BSBMV levels when in combination with BNYVV and the variability in BNYVV levels during co-infection could be a result of several factors. There may be competition for host infection sites by viruliferous $P$. betae. Alternatively, BNYVV-infected zoospores of $P$. betae may be more aggressive than BSBMVinfected zoospores of $P$. betae. The viruses may have a competitive advantage once inside the host cells. Another possible explanation for the relationship between these two viruses in mixed infections involves competition for replicative or movement proteins inside the host cells. Regardless of how these two viruses interact in sugar beet, attention should be paid to the possibility that the fresh weigh reductions observed in these studies indicate that BSBMV may also impact yield under field conditions. Efforts should be made to determine the extent of the effect of this virus on field production and to identify sources of resistance to BSBMV.

\section{LITERATURE CITED}

1. Abe, H., and Tamada, T. 1986. Association of beet necrotic yellow vein virus with isolates of Polymyxa betae Keskin. Ann. Phytopathol. Soc. Jpn. 52:235-247.

2. Barr, D. J. S. 1992. Evolution and kingdoms of organisms from the perspective of a mycologist. Mycologia 84:1-11.

3. Biancardi, E., Lewellen, R. T., DeBiaggi, M., Erichsen, A. W., and Stevanato, P. 2002. The origin of rhizomania resistance in sugar beet. Euphytica 127:383-397.

4. Canova, A. 1966. Ricerche virologiche nella rizomania della bietola. Ann. Accad. Naz. Agric. 78:37-46.

5. Duffus, J. E., Whitney, E. D., Larson, R. C., Liu, H. Y., and Lewellen, R. T. 1984. First report in Western hemisphere of rhizomania of sugar beet caused by beet necrotic yellow vein virus. Plant Dis. 68:251.

6. Gallian, J. J., Wintermantel, W. M., and Hamm, P. B. 2002. First report of rhizomania of sugar beet in the Columbia River Basin of Washington and Oregon. Plant Dis. 86:72.

7. Gerik, J. S., Jensen, C. S., and Duffus, J. E. 1987. Soil testing for Rhizomania. Calif. Sugar Beet 1987:17-28.

8. Harveson, R. M., Hein, G. L., Smith, J. A., Wilson, R. G., and Yonts, C. D. 2002. An integrated approach to cultivar evaluation and selection for improving sugar beet profitability. Plant Dis. 86:192-204.

9. Koenig, R., and Lesemann, D.-E. 2000. Genus Benyvirus. Pages 917-922 in: Virus Taxonomy. 7th Report of the International Committee on Taxonomy of Viruses. M. H. V. Van Regenmortel, C. M. Fauquet, and D. H. L. Bishop, eds. Academic Press, San Diego, CA.

10. Lee, L., Tedford, E. B., Batten, J. S., Scholthof, K.-B. G., and Rush, C. M. 2001. Complete nucleotide sequence and genome organization of Beet soil-borne mosaic virus. Arch. Virol. 146:2443-2453.

11. Lewellen, R. T. 1995. Performance of nearisolines of sugarbeet with resistance to rhizomania from different sources. Pages 83-91 in: Proc. 58th I.I.R.B Congress, Beaune, France.

12. Lewellen, R. T., and Biancardi, E. 1990. Breeding and performance of rhizomania resistant sugarbeet. Pages 69-87 in: Proc. 53rd 
Winter Congress, I.I.R.B., Brussels, Belgium.

13. Lewellen, R. T., Skoyen, I. O., and Erichsen, A. W. 1987. Breeding sugarbeet for resistance to rhizomania: evaluation of host-plant reactions and selection for and inheritance of resistance. Pages 139-156 in: Proc. 50th Winter Congress, I.I.R.B., Brussels, Belgium.

14. Liu, H.-Y., and Duffus, J. E. 1988. The occurrence of a complex of viruses associated with rhizomania of sugarbeet. (Abstr.) Phytopathology 78:1583.

15. Mahmood, T., and Rush, C. M. 1999. Evidence of cross-protection between beet soilborne mosaic virus and beet necrotic yellow vein virus in sugar beet. Plant Dis. 83:521-526.

16. Obermeier, C. 1998. DNA-gestützte Nachweisverfahren für den Virusübertragenden Bodenpilz Polymyxa betae und ihr Einsatz im Rizomania-Resistenztest bei Zuckerrüben. $\mathrm{Ph}$.D. thesis. Technischen Universitat CaroloWilhelmina zu Braunschweig, Germany.

17. Rush, C. M., French, R. C., and Heidel, G. B. 1993. Texas 7: A possible strain of beet necrotic yellow vein virus. Pages 59-62 in: Proc. Second Symp. Intl. Working Group Plant Viruses with Fungal Vectors, Montreal.

18. Rush, C. M., Heidel, G. B., French, R. C., and Lazar, M. D. 1993. Relationship between
BNYVV and an unnamed soilborne sugar beet virus from Texas. J. Sugar Beet Res. 30:114.

19. Rush, C. M., Scholthof, K.-B. G., Manohar, S. K., and Heidel, G. B. 1996. Similarities between beet soilborne mosaic virus and beet necrotic yellow vein virus RNA2 nucleotide sequence and genomic organization. Pages 29-32 in: Proc. Third Symp. Intl. Working Group Plant Viruses with Fungal Vectors, Dundee, Scotland.

20. Studier, F. W., Rosenberg, A. H., Dunn, J. J., and Dubendorff, J. W. 1990. Use of T7 RNA polymerase to direct expression of cloned genes. Methods Enzymol. 185:60-68.

21. Tamada, T., and Baba, T. 1973. Beet necrotic yellow vein virus from rhizomania-affected sugar beet in Japan. Ann. Phytopathol. Soc. Jpn. 39:325-332.

22. Tuitert, G., Musters-Van Oorschot, P. M. M., and Hiejbroek, W. 1994. Effect of sugar beet cultivars with different levels of resistance to beet necrotic yellow vein virus on transmission of virus by Polymyxa betae. Eur. J. Plant Pathol. 100:201-220.

23. Wintermantel, W. M., Crook, T., and Fogg, R. 2003. First report of rhizomania disease of sugar beet caused by Beet necrotic yellow vein virus in the Great Lakes production region. Plant Dis. 87:201.

24. Wisler, G. C. 2001. Furoviruses. Pages $491-$ 493 in: Encyclopedia of Plant Pathology. O. C. Maloy and T. D. Murray, eds. John Wiley \& Sons, New York.

25. Wisler, G. C., Lewellen, R. T., Sears, J. L., Liu, H.-Y., and Duffus, J. E. 1999. Specificity of TAS-ELISA for Beet necrotic yellow vein virus and its application for determining rhizomania resistance in field-grown sugar beets. Plant Dis. 83:864-870.

26. Wisler, G. C., Liu, H.-Y., and Duffus, J. E. 1994. Beet necrotic yellow vein virus and its relationship to eight sugar beet furo-like viruses from the United States. Plant Dis 78:995-1001.

27. Wisler, G. C., Liu, H.-Y., Li, R. H., and Duffus, J. E. 1996. Comparative molecular analysis of several BNYVV- and BSBMV-related furoviruses infecting sugarbeet. Pages 53-60 in: Proc. Third Symp. Intl. Working Group Plant Viruses with Fungal Vectors, Dundee, Scotland.

28. Wisler, G. C., Widner, J. N., Duffus, J. E., Liu, H.-Y., and Sears, J. L. 1997. A new report of rhizomania and other furoviruses infecting sugar beet in Minnesota. Plant Dis. 81:229. 